\title{
The most influential papers in mitral valve surgery; a bibliometric analysis
}

\author{
N. Allen ${ }^{*}\left(\mathbb{D}, \mathrm{K} . \mathrm{O}^{\prime}\right.$ Sullivan and J. M. Jones
}

\begin{abstract}
This study is an analysis of the 100 most cited articles in mitral valve surgery. A bibliometric analysis is a tool to evaluate research performance in a given field. It uses the number of times a publication is cited by others as a proxy marker of its impact. The most cited paper Carpentier et al. discusses mitral valve repair in terms of restoring the geometry of the entire valve rather than simply narrowing the annulus (Carpentier, J Thorac Cardiovasc Surg 86: 23-37, 1983). The first successful mitral valve repair was performed by Elliot Cutler at Brigham and Women's Hospital in 1923 (Cohn et al., Ann Cardiothorac Surg 4:315, 2015). More recently percutaneous and minimally invasive techniques that were originally designed as an option for high risk patients are being trialled in other patient groups (Hajar, Heart Views 19:160-3, 2018). Comparison of percutaneous method with open repair represents an expanding area of research (Hajar, Heart Views 19:160-3, 2018). This study will analyse the top 100 cited papers relevant to mitral valve surgery, identifying the most influential papers that guide current management, the institutions that produce them and the authors involved.
\end{abstract}

Keywords: Mitral valve, Mitral valve replacement, Mitral repair, Bibliometric analysis, Valve surgery, Cardiac surgery, Cardiovascular, Minimally invasive, Percutaneous surgery, Robotic surgery

\section{Introduction}

The first successful mitral valve surgery was performed in 1923 by Elliot C. Cutler, a student of Harvey Cushing, at Peter Bent Brigham Hospital (now incorporated in The Brigham and Women's Hospital) [1, 2]. A blind commissurotomy via the apex of the heart was performed for a young female patient with rheumatic mitral valve stenosis. Despite being comatose from low cardiac output preprocedure she was discharged 4 days later having made a good recovery [2]. Following this initial success others began to develop techniques to treat mitral valve disease. Sir Henry S. Souttar performed the first finger fracture of mitral stenosis in 1925. By 1964 Harken and Ellis produced a series of 1571 closed mitral valvuloplasties [3]. In 1986 Hansen et al. published a paper of trials in canine models emphasising the importance of preserving the mitral

\footnotetext{
*Correspondence: neill.allen@nhs.net

Department of Cardiothoracic Surgery, Royal Victoria Hospital, 274 Grosvenor Road, Belfast BT12 6BA, UK
}

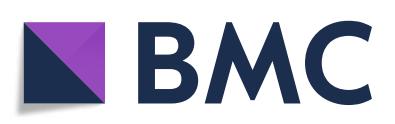

(c) The Author(s). 2020 Open Access This article is licensed under a Creative Commons Attribution 4.0 International License, which permits use, sharing, adaptation, distribution and reproduction in any medium or format, as long as you give appropriate credit to the original author(s) and the source, provide a link to the Creative Commons licence, and indicate if changes were made. The images or other third party material in this article are included in the article's Creative Commons licence, unless indicated otherwise in a credit line to the material. If material is not included in the article's Creative Commons licence and your intended use is not permitted by statutory regulation or exceeds the permitted use, you will need to obtain permission directly from the copyright holder. To view a copy of this licence, visit http://creativecommons.org/licenses/by/4.0/ The Creative Commons Public Domain Dedication waiver (http://creativecommons.org/publicdomain/zero/1.0/) applies to the data made available in this article, unless otherwise stated in a credit line to the data.
This led to a move towards repair rather than replacement that persists to the present day. More recently minimally invasive surgery, percutaneous intervention and robotic surgery have all developed into expanding areas of research [5]. To the best of our knowledge this study is the first to analyse the top cited papers in mitral valve surgery, using the number of citations as a proxy for the impact that paper has on the field. A number of other bibliometric analyses in other surgical specialties, and more broadly in cardiovascular surgical topics, have been published in recent years [69]. They have contributed to better understanding of the influential papers in their respective fields.

"A citation is an alphanumeric expression which acknowledges the relevance given by the author to the work of others on a topic of discussion in which the citation appears. It is an act of intellectual honesty" [6]. Using the number of citations a paper receives since its publication - citation analysis, the influence of a paper 
can be measured. Using a citation analysis, the impact factor of a journal can be determined. The impact factor is a measure of how many citations the average article in the journal receives in a year. These methods are not without their flaws - the intrinsic value of a paper is not directly correlated to the number of citations it receives [10]. The impact factor of a journal is determined by the papers a small number of reviewers deem suitable to be published in their journal; an inherently subjective process. While the use of citation analysis and impact factor are not perfect as measures of merit they are accepted as the best proxy measures of the impact of a paper and the journal it is published in [10]. The purpose of this paper is rank the top 100 cited papers in mitral valve surgery and analyse the journals, country of origin and top publishing institutions and authors using number of citations and impact factor as measures of impact on mitral valve surgery.

\section{Methods}

Journals related to cardiothoracic surgery or cardiovascular themes were included based on their 2018 impact factor. We used the Clarivate Analytics Journal Citation Reports database to identify 20 Journals with high impact factor (1.062-70.67). We then used Clarivate Analytics Web of Science to search for publications with the word "mitral" as a topic in the categories of "Surgery" and "Cardiac Cardiovascular Systems". This yielded 94,733 results of which the top cited 1250 were chosen for further review. From this list the Top 100 cited papers specific to mitral valve Surgery were selected. Published guidelines, papers on radiological investigation of mitral valve disease and purely medical management of mitral valve disease were excluded.

Once the top 100 articles were identified the title, authors, journal, country of origin, year of publication and number of citations were recorded. This data was then analysed to produce tables for the top 100 papers, the journals with the highest impact factor, the number of top 100 articles published per decade, number of articles per top journal, common research themes, authors with multiple publications, the country with the most top 100 papers and the institutions with most top 100 papers.

\section{Results}

Eleven Journals related to cardiac surgery or mitral valve disease with a high impact factor $(\geq 1.062)$ were included in the initial search (Table 1). The top 100 publications in each of these 11 journals was established (Table 2). The most frequently represented journals were Circulation (36 papers), Journal of Thoracic and Cardiovascular Surgery (34 papers) and Annals of Thoracic Surgery (23 papers) (Table 3). The paper with the highest number of
Table 1 List of journals included ranked by impact factor

\begin{tabular}{lll}
\hline Rank & Journal & 2018 Impact factor \\
\hline 1 & New England Journal of Medicine & 70.67 \\
2 & Lancet & 59.102 \\
3 & Journal of The American Medical & 51.273 \\
& Association \\
4 & Circulation & 23.054 \\
5 & Chest & 9.657 \\
6 & Journal of Thoracic and & 5.261 \\
7 & Cardiovascular Surgery \\
8 & Annals of Thoracic Surgery & 3.919 \\
& European Journal of Cardio-Thoracic & 3.847 \\
9 & Surgery & 1.179 \\
10 & Journal of cardiac surgery & 1.109 \\
& Annals of thoracic and & \\
11 & cardiovascular surgery & Journal of Cardiovascular Surgery \\
\hline
\end{tabular}

citations (1348) was "The French Correction" by Carpentier et al. [11]. A functional classification was described with related mitral valve repair methods using extensive leaflet resection, chordal manipulation, and annuloplasty to restore a functioning valve [107]. The lowest cited paper included received 148 citations. The mean number of citations a paper received was 248 . The oldest paper was published in 1960 and was ranked 64th. It describes techniques for mitral repair due to chordae tendineae rupture. Most of the papers in the top 100 were published in the 1990s (35 papers) (Table 4).

The topics covered followed several recurring themes. Most common were papers comparing various methods of surgical repair. Other common themes were risk stratification, rates of complication, long term outcomes and minimally invasive, percutaneous and robotic techniques (Table 5). Various first authors have multiple papers in the top 100. Tirone E. David features 6 times as first author in the top 100 with papers describing repair and replacement techniques. Alain Carpentier is listed as first author for 5 papers - the top cited papers and several others describing mitral valve repair. A further 11 authors have multiple first authorships Bolling, Braun, Cohn, Edmunds, Gammie, Gillinov, Jamieson, Mohr, Palacios, Schoen and Webb (Table 6).

Looking at the country of origin; most papers were from the United States of America (50 papers) with Canada and France representing 2nd and 3rd places with 13 and 9 papers respectively. A total of 15 countries were represented individually (Table 7). The highest publishing institution was The Mayo Clinic with Toronto General Hospital and The Cleveland Clinic in second and third places (Table 8). 
Table 2 List of most cited papers by first author and number of citations

\begin{tabular}{|c|c|c|c|c|c|}
\hline & \\
\hline Rank & First Author & Total Citations & Rank & First Author & Total Citations \\
\hline 1 & Carpentier, A [11] & 1348 & 44 & Navia, J [51] & 210 \\
\hline 2 & Inoue, K [12] & 842 & 45 & Shinoka, T [52] & 209 \\
\hline 3 & Cannegieter, S [13] & 657 & 46 & Schoen, F [53] & 208 \\
\hline 4 & O'Brien, S [14] & 601 & 47 & Rankin, J [54] & 202 \\
\hline 5 & Enriquezsarano, M [15] & 499 & 48 & Kron, I [55] & 201 \\
\hline 6 & Carpentier, A [16] & 495 & 49 & Rieder, E [56] & 201 \\
\hline 7 & Alfieri, O [17] & 462 & 50 & Messas, E [57] & 200 \\
\hline 8 & Bolling, S [18] & 443 & 51 & Thomas, J [58] & 199 \\
\hline 9 & McGee, E [19] & 414 & 52 & Altman, R [59] & 199 \\
\hline 10 & Shroyer, A [20] & 407 & 53 & Nobuyoshi, M [60] & 196 \\
\hline 11 & Carpentier, A [21] & 403 & 54 & Schofer, J [61] & 193 \\
\hline 12 & Gillinov, A [22] & 375 & 55 & Calafiore, A [62] & 191 \\
\hline 13 & Gillinov, A [23] & 374 & 56 & Amoury, R [63] & 185 \\
\hline 14 & Schoen, F [24] & 362 & 57 & David, T [64] & 184 \\
\hline 15 & Webb, J [25] & 358 & 58 & Crawford, M [65] & 183 \\
\hline 16 & Carpentier, A [21] & 332 & 59 & Fucci, C [66] & 180 \\
\hline 17 & Devereux, R [26] & 330 & 60 & Gammie, J [67] & 179 \\
\hline 18 & Palacios, I [27] & 315 & 61 & Wendel, H [68] & 178 \\
\hline 19 & Pibarot, P [28] & 312 & 62 & Flameng, W [69] & 177 \\
\hline 20 & Rosenhek, R [29] & 301 & 63 & Rozich, J [70] & 175 \\
\hline 21 & Deloche, A [30] & 290 & 64 & Jamieson, W [71] & 174 \\
\hline 22 & Bolling, S [31] & 261 & 65 & Webb, J [72] & 174 \\
\hline 23 & Tribouilloy, C [32] & 259 & 66 & McGoon, D & 174 \\
\hline 24 & Mohr, F [33] & 253 & 67 & Ling, L [73] & 173 \\
\hline 25 & Bjork, V [34] & 252 & 68 & Vyavahare, N [74] & 172 \\
\hline 26 & Suri, R [35] & 242 & 69 & Perier, P [75] & 171 \\
\hline 27 & Carpentier, A [36] & 237 & 70 & Ambler, G [76] & 171 \\
\hline 28 & Modi, P [37] & 234 & 71 & Chua, Y [77] & 170 \\
\hline 29 & Edwards, F [38] & 231 & 72 & Bolling, S [78] & 169 \\
\hline 30 & Palacios, I [39] & 231 & 73 & Masur, H [79] & 169 \\
\hline 31 & Maisano, F [40] & 231 & 74 & Braun, J [80] & 167 \\
\hline 32 & David, T & 231 & 75 & John, S [81] & 167 \\
\hline 33 & Carabello, B [41] & 229 & 76 & Gammie, J [82] & 167 \\
\hline 34 & David, T [42] & 228 & 77 & Bodner, J [83] & 167 \\
\hline 35 & Mohr, F & 225 & 78 & David, T [84] & 163 \\
\hline 36 & Schuler, G [43] & 223 & 79 & Cox, J [85] & 162 \\
\hline 37 & Cosgrove, D [44] & 221 & 80 & Hickey, M [86] & 161 \\
\hline 38 & Lillehei, C [45] & 221 & 81 & Kang, D [87] & 160 \\
\hline 39 & Grossi, E [46] & 218 & 82 & Acar, J [88] & 159 \\
\hline 40 & Geha, A [47] & 217 & 83 & Fattouch, K [89] & 159 \\
\hline 41 & Braunberger, E [48] & 214 & 84 & King, R [90] & 158 \\
\hline 42 & Edmunds, L [49] & 212 & 85 & Abascal, V [91] & 156 \\
\hline 43 & Edmunds, L [50] & 212 & 86 & Magne, J [92] & 156 \\
\hline
\end{tabular}

Table 2 List of most cited papers by first author and number of citations (Continued) 
Table $\mathbf{2}$ List of most cited papers by first author and number of citations (Continued)

\begin{tabular}{lll}
\hline Rank & First Author & Total Citations \\
\hline 87 & Rossiter, S [93] & 156 \\
88 & Jamieson, W [94] & 155 \\
89 & Kosakai, Y [95] & 153 \\
90 & Borger, M [96] & 152 \\
91 & Mohty, D [97] & 152 \\
92 & David, T [98] & 152 \\
93 & Cohn, L [99] & 151 \\
94 & Cohn, L [100] & 151 \\
95 & Dreyfus, G [101] & 151 \\
96 & Braun, J [102] & 150 \\
97 & David, T [103] & 150 \\
98 & Ben F [104] & 149 \\
99 & Chauvaud, S [105] & 148 \\
100 & Seeburger, J [106] & 147
\end{tabular}

\section{Discussion}

The first surgical intervention on the mitral valve was performed as a blind commissurotomy for a patient in extremis by E.C. Cutler in 1923 [2]. The patient had a rheumatic valve, a common aetiology that drove early interest in mitral valve surgery. Open surgery for mitral disease did not become possible until the invention of cardiopulmonary bypass by Dr. John Gibbon in the late 1930s [108]. C. Walton Lillehei is credited with the first mitral valve repair for mitral insufficiency in 1960 [109]. The importance of preserving mitral apparatus was described by Hansen et al. leading to a preference for repair of the patient's own valve rather than replacement wherever possible [4].

More recently mitral surgery research has begun to examine the use of percutaneous, minimally invasive and robotic surgery [110, 111]. Repair of the mitral valve has been propelled by research into new techniques for repair, comparing repair over replacement, and more recently the comparison of minimally invasive and robotic techniques compared to open repair. A number

Table 3 List of journals where the most cited papers can be found

\begin{tabular}{lll}
\hline Rank & Journal & $\begin{array}{l}\text { Number of } \\
\text { Articles }\end{array}$ \\
\hline 1 & Circulation & 36 \\
2 & $\begin{array}{l}\text { Journal of Thoracic and } \\
\text { Cardiovascular Surgery }\end{array}$ & 34 \\
3 & Annals of Thoracic Surgery & 23 \\
4 & European Journal of & 7 \\
\hline
\end{tabular}

Table 4 Number of top cited papers per decade

\begin{tabular}{ll}
\hline Decade & Number of Articles \\
\hline $1960 s$ & 4 \\
$1970 s$ & 6 \\
$1980 s$ & 18 \\
$1990 s$ & 35 \\
$2000 s$ & 34 \\
$2010 s$ & 3 \\
\hline
\end{tabular}

of key papers include McGoon et al. "Repair of mitral insufficiency due to ruptured chordae tendineae" [112] in 1960 and later Carpentier et al. "The French Correction" [11] in 1983. In 1994 Cohn et al. demonstrated the benefits of repair over replacement of the mitral valve whenever possible [113].

The most frequently cited paper in our analysis is "The French Correction" first presented by Carpentier as the Honoured Guest's Address to The American Association for Thoracic Surgery in Atlanta 1983, emphasised the need to focus on function rather than valve lesions. This functional analysis has become the foundation of valve assessment and reconstruction.

Papers discussing percutaneous, minimally invasive and robotic techniques include "Clinical Applications of Transvenous Mitral Commissurotomy by a New Balloon Catheter" by Inoue et al. 1984. This highly cited paper (842 citations) discussed 6 patients who had successful treatment of mitral stenosis using mitral commissurotomy using a balloon catheter inserted via the Saphenous vein.

"Transcatheter valve-in-valve implantation for failed bioprosthetic heart valves." Webb et al. 2010 demonstrated that transcatheter valve-in-valve insertion was feasible. Their study included 24 patients, 6 of whom had their mitral valve replaced using this percutaneous method.

Regarding robotic surgery "Computer-enhanced robotic cardiac surgery: Experience in 148 patients" Mohr et al. 2001 reported on 17 patient undergoing robotic mitral valve surgery 14 of these patients had their

Table $\mathbf{5}$ List of common themes from the top papers

\begin{tabular}{lll}
\hline Rank & Topic & Number of Articles \\
\hline 1 & Repair/replacement techniques & 32 \\
2 & Risk Stratification & 21 \\
3 & Complications & 14 \\
4 & Long term outcomes & 12 \\
5 & Minimally invasive/Robotic & 10 \\
6 & Percutaneous techniques & 9 \\
7 & Other & 2 \\
\hline
\end{tabular}


Table 6 Authors with multiple first authorship of 100 most cited papers

\begin{tabular}{lll}
\hline Rank & First Author & $\begin{array}{l}\text { Frequency of } \\
\text { First Authorship }\end{array}$ \\
\hline 1 & David, T & 6 \\
2 & Carpentier, A & 5 \\
3 & Bolling, S & 3 \\
4 & Braun, J & 2 \\
5 & Cohn, L & 2 \\
6 & Edmunds, L & 2 \\
7 & Gammie, J & 2 \\
8 & Gillinov, A & 2 \\
9 & Jamieson, W & 2 \\
10 & Mohr, F & 2 \\
11 & Palacios, I & 2 \\
12 & Schoen, F & 2 \\
13 & Webb, J & 2 \\
\hline
\end{tabular}

procedure completed robotically. They concluded this type of robotic surgery was feasible and safe [114].

Typically surgical papers are published in a small number of specialised journals dedicated to that speciality [7]. In this analysis we have also found this to be the case. Despite searching 11 journals with a high impact factor and cardiac surgery theme our top 100 papers came from just 4 journals. Given the specialist nature of mitral surgery repair this is not entirely surprising. Papers discussing repair techniques are most often found in surgical themed journals. However, some papers discussing percutaneous valve repair and risk

Table 7 Countries with multiple published papers

\begin{tabular}{lll}
\hline Rank & Country & $\begin{array}{l}\text { Number of top } \\
100 \text { papers }\end{array}$ \\
\hline 1 & USA & 50 \\
2 & Canada & 13 \\
3 & France & 9 \\
4 & Germany & 7 \\
5 & Italy & 5 \\
6 & Netherlands & 3 \\
6 & Japan & 3 \\
6 & Austria & 3 \\
7 & UK & 1 \\
7 & Tunisia & 1 \\
7 & South Korea & 1 \\
7 & India & 1 \\
7 & Finland & 1 \\
7 & Belgium & 1 \\
7 & Argentina & 1 \\
\hline
\end{tabular}

Table 8 Institutes that have published multiple most cited papers

\begin{tabular}{|c|c|}
\hline Institution & Frequency \\
\hline Mayo Clinic, Rochester, MN, USA & 7 \\
\hline $\begin{array}{l}\text { Toronto General Hospital and the } \\
\text { University of Toronto, Toronto, } \\
\text { ON, Canada }\end{array}$ & 7 \\
\hline $\begin{array}{l}\text { The University of Michigan, Ann } \\
\text { Arbor, MI, USA }\end{array}$ & 5 \\
\hline $\begin{array}{l}\text { Cleveland Clinic Foundation, } \\
\text { Cleveland, OH, USA. }\end{array}$ & 5 \\
\hline $\begin{array}{l}\text { Massachusetts General Hospital, } \\
\text { Boston, MA, USA }\end{array}$ & 5 \\
\hline $\begin{array}{l}\text { Hôpital Européen Georges } \\
\text { Pompidou, Université René } \\
\text { Descartes, Paris, France. }\end{array}$ & 4 \\
\hline $\begin{array}{l}\text { Brigham and Women's Hospital, } \\
\text { Boston, MA, USA }\end{array}$ & 4 \\
\hline $\begin{array}{l}\text { St. Paul's Hospital, University of } \\
\text { British Columbia, Vancouver, BC, } \\
\text { Canada }\end{array}$ & 4 \\
\hline Hospital Broussais, Paris, France. & 4 \\
\hline $\begin{array}{l}\text { University Hospital Leiden, } \\
\text { The Netherlands }\end{array}$ & 3 \\
\hline $\begin{array}{l}\text { Heart Center, University of Leipzig, } \\
\text { Leipzig, Germany }\end{array}$ & 3 \\
\hline $\begin{array}{l}\text { Laval Hospital Research Center/ } \\
\text { Québec Heart Institute, } \\
\text { Laval University, Québec, Canada }\end{array}$ & 2 \\
\hline $\begin{array}{l}\text { Medical University of Vienna, } \\
\text { Vienna, Austria. }\end{array}$ & 2 \\
\hline $\begin{array}{l}\text { East Carolina Heart Institute, } \\
\text { Greenville, NC, USA. }\end{array}$ & 2 \\
\hline $\begin{array}{l}\text { IRCCS S. Raffaele Hospital, } \\
\text { Milano, Italy. }\end{array}$ & 2 \\
\hline $\begin{array}{l}\text { Duke Clinical Research Institute, } \\
\text { Durham, NC, USA. }\end{array}$ & 2 \\
\hline $\begin{array}{l}\text { University of Pennsylvania School } \\
\text { of Medicine, Philadelphia, PA, USA }\end{array}$ & 2 \\
\hline Children's Hospital, Boston, MA, USA. & 2 \\
\hline $\begin{array}{l}\text { University of Maryland Medical } \\
\text { Center, Baltimore, MD, USA }\end{array}$ & 2 \\
\hline
\end{tabular}

stratification can be found in Cardiology or medical journals with a high journal impact factor. In this analysis we have demonstrated that the inclusion of such journals is necessary to ensure high impact papers affecting mitral surgery are not overlooked.

Often highly cited papers are those that have been published less recently as they have time to accrue more citations. In our analysis this is not the case, with 37 of the top papers published after 2000; demonstrating the ongoing evolution of research in this field. The number of citations a paper receives is a limited measure of merit. However, it can be useful in judging the impact 
that paper has had on its field [10]. Journal impact factor is a better measure of merit in that a paper must be deemed of adequate quality to warrant publication in a widely read journal. Often this is determined by a small number of experts in that field. Peer Review is another mechanism that helps ensure papers published in journals with high impact factor are of high quality. Any research with flawed methodology is likely to be identified and a redaction made.

\section{Conclusion}

Using this analysis, the most influential papers in mitral valve surgery in the modern era are those describing repair techniques. The most cited paper restored faith in mitral valve repair, improved its reliability and reduced the incidence of replacements. This often results in improved outcomes for patients not only from having their own mitral apparatus but avoiding prostheses and the need for lifelong anticoagulation.

Citation analyses of this type, while imperfect, do offer a useful overview of research in a field. Our bibliometric analysis demonstrates the progress made by mitral valve research and its future with investigation of percutaneous and robotic techniques. This analysis demonstrates the evidence-based approach used by cardiac surgeons today and the continued re-evaluation of mitral valve surgery to ensure the best possible outcomes for patients with mitral valve disease.

\section{Acknowledgements}

Not applicable.

\section{Authors' contributions}

NA acquired the data set, analysed the data and drafted the manuscript, KO'S contributed to the concept of the manuscript, edited and revised the manuscript. MJ substantively revised the manuscript. The author(s) read and approved the final manuscript.

\section{Funding}

Kindly supported by Cancer Challenge Fund.

\section{Availability of data and materials}

The datasets used and/or analysed during the current study are available from the corresponding author on reasonable request.

\section{Ethics approval and consent to participate}

Not applicable.

\section{Consent for publication}

Not applicable.

\section{Competing interests}

The authors declare that they have no competing interests.

Received: 9 September 2019 Accepted: 1 July 2020

Published online: 20 July 2020

\section{References}

1. Cohn LH, Tchantchaleishvili V, Rajab TK. Evolution of the concept and practice of mitral valve repair. Ann Cardiothorac Surg. 2015;4(4):315 Available from: http://www.ncbi.nlm.nih.gov/pubmed/26309840. Cited 2019 Jul 15.
2. Cutler EC, Levine SA. Cardiotomy and valvulotomy for mitral stenosis; experimental observations and clinical notes concerning an operated case with recovery. Bost Med Surg J. 1923;188(26):1023-7 Available from: http://www.nejm.org/doi/abs/10.1056/NEJM192306281882601. Cited 2019 Jul 16.

3. Ellis LB, Harken DE. Closed valvuloplasty for mitral stenosis. N Engl J Med. 1964;270(13):643-50 Available from: http://www.nejm.org/doi/abs/10.1056/ NEJM196403262701301. Cited 2019 Jul 16.

4. Hansen DE, Cahill PD, DeCampli WM, Harrison DC, Derby GC, Mitchell $\mathrm{RS}$, et al. Valvular-ventricular interaction: importance of the mitral apparatus in canine left ventricular systolic performance. Circulation. 1986;73(6):1310-20 Available from: http://www.ncbi.nlm.nih.gov/ pubmed/3698258. Cited 2019 Jul 16.

5. Hajar R. Historical perspective on percutaneous mitral valve repair. Heart Views. 2018;19(4):160-3 Available from: http://www.ncbi.nlm.nih.gov/ pubmed/31057713. Cited 2019 Jul 15

6. Kelly JC, Glynn RW, O'Briain DE, Felle P, McCabe JP. The 100 classic papers of orthopaedic surgery. J Bone Joint Surg Br. 2010;92-B(10):1338-43 Available from: http://online.boneandjoint.org.uk/doi/10.1302/0301-620X.92 B10.24867. Cited 2019 May 23.

7. O'Sullivan KE, Kelly JC, Hurley JP. The 100 most cited publications in cardiac surgery: a bibliometric analysis. Irish J Med Sci (1971 -). 2015; 184(1):91-9 Available from: http://www.ncbi.nlm.nih.gov/pubmed/252 08821. Cited 2019 May 23.

8. Hurley JP, Hurley JP. The 100 most cited publications in transplantation. Ann Transplant. 2014;19:436-43 Available from: http://www.ncbi.nlm.nih.gov/ pubmed/25183295. Cited 2019 May 23.

9. Lai P, Liu Y, Xue J, He P, Qiu Y. The 100 most-cited articles on aortic dissection. BMC Cardiovasc Disord. 2017;17(1):30 Available from: http:// www.ncbi.nlm.nih.gov/pubmed/28095771. Cited 2019 May 23.

10. Eyre-Walker A, Stoletzki N. The assessment of science: the relative merits of post-publication review, the impact factor, and the number of citations. Eisen JA, editor. PLoS Biol. 2013;11(10):e1001675 Available from: http://dx. plos.org/10.1371/journal.pbio.1001675. Cited 2019 May 23.

11. Carpentier A. Cardiac valve surgery--the "French correction". J Thorac Cardiovasc Surg. 1983;86(3):323-37 Available from: http://www.ncbi.nlm.nih. gov/pubmed/6887954. Cited 2019 Aug 5.

12. Inoue K, Owaki T, Nakamura T, Kitamura F, Miyamoto N. Clinical application of transvenous mitral commissurotomy by a new balloon catheter. J Thorac Cardiovasc Surg. 1984;87(3):394-402 Available from: http://www.ncbi.nlm. nih.gov/pubmed/6700245. Cited 2019 Aug 14.

13. Cannegieter SC, Rosendaal FR, Briët E. Thromboembolic and bleeding complications in patients with mechanical heart valve prostheses. Circulation. 1994;89(2):635-41 Available from: http://www.ncbi.nlm.nih.gov/ pubmed/8313552. Cited 2019 Aug 14.

14. O'Brien SM, Shahian DM, Filardo G, Ferraris VA, Haan CK, Rich JB, et al. The society of thoracic surgeons 2008 cardiac surgery risk models: part 2-isolated valve surgery. Ann Thorac Surg. 2009;88(1 Suppl):S23-42 Available from: https://linkinghub.elsevier.com/retrieve/pii/S0003497509010595. Cited 2019 Aug 14

15. Enriquez-Sarano M, Schaff HV, Orszulak TA, Tajik AJ, Bailey KR, Frye RL. Valve repair improves the outcome of surgery for mitral regurgitation. A multivariate analysis. Circulation. 1995;91(4):1022-8 Available from: http:// www.ncbi.nlm.nih.gov/pubmed/7850937. Cited 2019 Aug 14.

16. Carpentier A, Chauvaud S, Fabiani JN, Deloche A, Relland J, Lessana A, et al. Reconstructive surgery of mitral valve incompetence: ten-year appraisal. J Thorac Cardiovasc Surg. 1980;79(3):338-48 Available from: http://www.ncbi. nlm.nih.gov/pubmed/7354634. Cited 2019 Aug 14.

17. Alfieri O, Maisano F, De Bonis M, Stefano PL, Torracca L, Oppizzi M, et al. The double-orifice technique in mitral valve repair: a simple solution for complex problems. J Thorac Cardiovasc Surg. 2001;122(4):674-81 Available from: https://linkinghub.elsevier.com/retrieve/pii/S0022522301635724. Cited 2019 Aug 14.

18. Bolling SF, Pagani FD, Deeb GM, Bach DS. Intermediate-term outcome of mitral reconstruction in cardiomyopathy. J Thorac Cardiovasc Surg. 1998; 115(2):381-8 Available from: http://www.ncbi.nlm.nih.gov/pubmed/9475533. Cited 2019 Aug 14.

19. McGee EC, Gillinov AM, Blackstone EH, Rajeswaran J, Cohen G, Najam F, et al. Recurrent mitral regurgitation after annuloplasty for functional ischemic mitral regurgitation. J Thorac Cardiovasc Surg. 2004;128(6):916-24 Available from: http://www.ncbi.nlm.nih.gov/pubmed/15573077. Cited 2019 Aug 14. 
20. Shroyer ALW, Coombs LP, Peterson ED, Eiken MC, DeLong ER, Chen A et al. The society of thoracic surgeons: 30-day operative mortality and morbidity risk models. Ann Thorac Surg. 2003;75(6):1856-64 discussion 1864-5. Available from: http://www.ncbi.nlm.nih.gov/pubmed/12822628. Cited 2019 Aug 14

21. Carpentier A, Lemaigre G, Robert L, Carpentier S, Dubost C. Biological factors affecting long-term results of valvular heterografts. J Thorac Cardiovasc Surg. 1969;58(4):467-83 Available from: http://www.ncbi.nlm.nih. gov/pubmed/5344189. Cited 2019 Aug 14.

22. Gillinov AM, Wierup PN, Blackstone EH, Bishay ES, Cosgrove DM, White J, et al. Is repair preferable to replacement for ischemic mitral regurgitation? J Thorac Cardiovasc Surg. 2001;122(6):1125-41 Available from: http://www. ncbi.nlm.nih.gov/pubmed/11726887. Cited 2019 Aug 14.

23. Gillinov AM, Cosgrove DM, Blackstone EH, Diaz R, Arnold JH, Lytle BW, et al. Durability of mitral valve repair for degenerative disease. J Thorac Cardiovasc Surg. 1998;116(5):734-43 Available from: http://www.ncbi.nlm. nih.gov/pubmed/9806380. Cited 2019 Aug 14

24. Schoen FJ, Levy RJ. Calcification of tissue heart valve substitutes: progress toward understanding and prevention. Ann Thorac Surg. 2005;79(3):1072-80 Available from: https://linkinghub.elsevier.com/retrieve/pii/S0003497504 013219. Cited 2019 Aug 14.

25. Webb JG, Wood DA, Ye J, Gurvitch R, Masson J-B, Rodés-Cabau J, et al. Transcatheter valve-in-valve implantation for failed bioprosthetic heart valves. Circulation. 2010;121(16):1848-57 Available from: http://www.ncbi. nlm.nih.gov/pubmed/20385927. Cited 2019 Aug 14.

26. Devereux RB, Perloff JK, Reichek N, Josephson ME. Mitral valve prolapse. Circulation. 1976;54(1):3-14 Available from: http://www.ncbi.nlm.nih.gov/ pubmed/776440. Cited 2019 Aug 14.

27. Palacios I, Block PC, Brandi S, Blanco P, Casal H, Pulido J, et al. Percutaneous balloon valvotomy for patients with severe mitral stenosis. Circulation. 1987; 75(4):778-84 Available from: http://www.ncbi.nlm.nih.gov/pubmed/3829341. Cited 2019 Aug 14.

28. Pibarot P, Dumesnil JG. Prosthetic heart valves. Circulation. 2009;119(7): 1034-48 Available from: http://www.ncbi.nlm.nih.gov/pubmed/19237674. Cited 2019 Aug 14.

29. Rosenhek R, Rader F, Klaar U, Gabriel H, Krejc M, Kalbeck D, et al. Outcome of watchful waiting in asymptomatic severe mitral regurgitation. Circulation. 2006;113(18):2238-44 Available from: http://www.ncbi.nlm.nih.gov/ pubmed/16651470. Cited 2019 Aug 14.

30. Deloche A, Jebara VA, Relland JY, Chauvaud S, Fabiani JN, Perier P, et al. Valve repair with Carpentier techniques. The second decade. J Thorac Cardiovasc Surg. 1990;99(6):990-1001 discussion 1001-2. Available from: http://www.ncbi.nlm.nih.gov/pubmed/2359339. Cited 2019 Aug 14.

31. Bolling SF, Deeb GM, Brunsting LA, Bach DS. Early outcome of mitral valve reconstruction in patients with end-stage cardiomyopathy. J Thorac Cardiovasc Surg. 1995;109(4):676-83 Available from: http://www.ncbi.nlm. nih.gov/pubmed/7715214. Cited 2019 Aug 14

32. Tribouilloy CM, Enriquez-Sarano M, Schaff HV, Orszulak TA, Bailey KR, Tajik AJ, et al. Impact of preoperative symptoms on survival after surgical correction of organic mitral regurgitation: rationale for optimizing surgical indications. Circulation. 1999;99(3):400-5 Available from: http://www.ncbi. nlm.nih.gov/pubmed/9918527. Cited 2019 Aug 14.

33. Mohr FW, Falk V, Diegeler A, Walther T, van Son JAM, Autschbach $R$, et al. Minimally invasive port-access mitral valve surgery. J Thorac Cardiovasc Surg. 1998;115(3):567-76 Available from: http://www.ncbi.nlm.nih.gov/ pubmed/9535444. Cited 2019 Aug 14.

34. Björk VO, Henze A. Ten years' experience with the Björk-Shiley tilting disc valve. J Thorac Cardiovasc Surg. 1979;78(3):331-42 Available from: http:// www.ncbi.nlm.nih.gov/pubmed/470414. Cited 2019 Aug 14.

35. Suri RM, Schaff HV, Dearani JA, Sundt TM, Daly RC, Mullany CJ, et al. Survival advantage and improved durability of mitral repair for leaflet prolapse subsets in the current era. Ann Thorac Surg. 2006;82(3):819-26 Available from: https://linkinghub.elsevier.com/retrieve/pii/S0003497506006515. Cited 2019 Aug 14.

36. Carpentier AF, Lessana A, Relland JY, Belli E, Mihaileanu S, Berrebi AJ, et al. The "physio-ring": an advanced concept in mitral valve annuloplasty. Ann Thorac Surg. 1995;60(5):1177-85 discussion 1185-6. Available from: https:// linkinghub.elsevier.com/retrieve/pii/0003497595007538. Cited 2019 Aug 14

37. Modi P, Hassan A, Chitwood WR. Minimally invasive mitral valve surgery: a systematic review and meta-analysis. Eur J Cardio-Thoracic Surg. 2008;34(5):
943-52 Available from: http://www.ncbi.nlm.nih.gov/pubmed/18829343. Cited 2019 Aug 14

38. Edwards FH, Hale D, Cohen A, Thompson L, Pezzella AT, Virmani R. Primary cardiac valve tumors. Ann Thorac Surg. 1991;52(5):1127-31 Available from: http://www.ncbi.nlm.nih.gov/pubmed/1953134. Cited 2019 Aug 14.

39. Palacios IF, Block PC, Wilkins GT, Weyman AE. Follow-up of patients undergoing percutaneous mitral balloon valvotomy. Analysis of factors determining restenosis. Circulation. 1989;79(3):573-9 Available from: https:// www.ahajournals.org/doi/10.1161/01.CIR.79.3.573. Cited 2019 Aug 14.

40. Maisano F, Torracca L, Oppizzi M, Stefano PL, D'Addario G, La Canna G, et al. The edge-to-edge technique: a simplified method to correct mitral insufficiency. Eur J Cardiothorac Surg. 1998;13(3):240-5 discussion 245-6. Available from: http:// www.ncbi.nlm.nih.gov/pubmed/9628372. Cited 2019 Aug 14.

41. Carabello BA, Nolan SP, McGuire LB. Assessment of preoperative left ventricular function in patients with mitral regurgitation: value of the endsystolic wall stress-end-systolic volume ratio. Circulation. 1981;64(6):1212-7 Available from: https://www.ahajournals.org/doi/10.1161/01.CIR.64.6.1212. Cited 2019 Aug 14.

42. David TE, Uden DE, Strauss HD. The importance of the mitral apparatus in left ventricular function after correction of mitral regurgitation. Circulation. 1983;68(3 Pt 2):I176-82 Available from: http://www.ncbi.n/m.nih.gov/ pubmed/6872199. Cited 2019 Aug 14

43. Schuler G, Peterson KL, Johnson A, Francis G, Dennish G, Utley J, et al. Temporal response of left ventricular performance to mitral valve surgery. Circulation. 1979;59(6):1218-31 Available from: http://www.ncbi.nlm.nih.gov/ pubmed/436214. Cited 2019 Aug 14.

44. Cosgrove DM, Sabik JF, Navia JL. Minimally invasive valve operations. Ann Thorac Surg. 1998;65(6):1535-8 discussion 1538-9. Available from: http:// www.ncbi.nlm.nih.gov/pubmed/9647054. Cited 2019 Aug 14.

45. Lillehei CW, Levy MJ, Bonnabeau RC. Mitral valve replacement with preservation of papillary muscles and chordae tendineae. J Thorac Cardiovasc Surg. 1964;47:532-43 Available from: http://www.ncbi.nlm.nih. gov/pubmed/14180754. Cited 2019 Aug 14

46. Grossi EA, Goldberg JD, LaPietra A, Ye X, Zakow P, Sussman M, et al. Ischemic mitral valve reconstruction and replacement: comparison of longterm survival and complications. J Thorac Cardiovasc Surg. 2001:122(6): 1107-24 Available from: https://linkinghub.elsevier.com/retrieve/pii/ S0022522301039046. Cited 2019 Aug 14.

47. Geha AS, Laks H, Stansel HC, Cornhill JF, Kilman JW, Buckley MJ, et al. Late failure of porcine valve heterografts in children. J Thorac Cardiovasc Surg. 1979;78(3):351-64 Available from: http://www.ncbi.nlm.nih.gov/pubmed/4 70416. Cited 2019 Aug 25.

48. Braunberger E, Deloche A, Berrebi A, Abdallah F, Celestin JA, Meimoun P, et al. Very long-term results (more than 20 years) of valve repair with carpentier's techniques in nonrheumatic mitral valve insufficiency. Circulation. 2001;104(12 Suppl 1):18-11 Available from: http://www.ncbi.nlm. nih.gov/pubmed/11568021. Cited 2019 Aug 14.

49. Edmunds LH. Thromboembolic complications of current cardiac valvular prostheses. Ann Thorac Surg. 1982;34(1):96-106 Available from: http://www. ncbi.nlm.nih.gov/pubmed/7046665. Cited 2019 Aug 14.

50. Edmunds $\mathrm{LH}$. Thrombotic and bleeding complications of prosthetic heart valves. Ann Thorac Surg. 1987;44(4):430-45 Available from: http://www.ncbi. nlm.nih.gov/pubmed/3310938. Cited 2019 Aug 14.

51. Navia $J$, Cosgrove DM. Minimally invasive mitral valve operations. Ann Thorac Surg. 1996;62(5):1542-4 Available from: http://www.ncbi.nlm.nih.gov/ pubmed/8893611. Cited 2019 Aug 14

52. Shinoka T, Breuer CK, Tanel RE, Zund G, Miura T, Ma PX, et al. Tissue engineering heart valves: valve leaflet replacement study in a lamb model. Ann Thorac Surg. 1995;60(6 Suppl):S513-6 Available from: https://linkinghub. elsevier.com/retrieve/pii/0003497595007334. Cited 2019 Aug 14.

53. Schoen FJ. Evolving concepts of cardiac valve dynamics: the continuum of development, functional structure, pathobiology, and tissue engineering. Circulation. 2008;118(18):1864-80 Available from: https://www.ahajournals. org/doi/10.1161/CIRCULATIONAHA.108.805911. Cited 2019 Aug 14.

54. Rankin JS, Hammill BG, Ferguson TB, Glower DD, O'Brien SM, DeLong ER, et al. Determinants of operative mortality in valvular heart surgery. J Thorac Cardiovasc Surg. 2006;131(3):547-57 Available from: http://www.ncbi.nlm. nih.gov/pubmed/16515904. Cited 2019 Aug 14.

55. Kron IL, Green GR, Cope JT. Surgical relocation of the posterior papillary muscle in chronic ischemic mitral regurgitation. Ann Thorac Surg. 2002; 
74(2):600-1 Available from: http://www.ncbi.nlm.nih.gov/pubmed/12173864. Cited 2019 Aug 14.

56. Rieder E, Kasimir M-T, Silberhumer G, Seebacher G, Wolner E, Simon P, et al. Decellularization protocols of porcine heart valves differ importantly in efficiency of cell removal and susceptibility of the matrix to recellularization with human vascular cells. J Thorac Cardiovasc Surg. 2004;127(2):399-405 Available from: https://linkinghub.elsevier.com/retrieve/pii/S0022522303016 015. Cited 2019 Aug 14.

57. Messas E, Guerrero JL, Handschumacher MD, Conrad C, Chow CM, Sullivan $S$, et al. Chordal cutting: a new therapeutic approach for ischemic mitral regurgitation. Circulation. 2001;104(16):1958-63 Available from: https://www. ahajournals.org/doi/10.1161/hc4201.097135. Cited 2019 Aug 14.

58. Thomas JD, Wilkins GT, Choong CY, Abascal VM, Palacios IF, Block PC, et al. Inaccuracy of mitral pressure half-time immediately after percutaneous mitral valvotomy. Dependence on transmitral gradient and left atrial and ventricular compliance. Circulation. 1988;78(4):980-93 Available from: https://www.ahajournals.org/doi/10.1161/01.CIR.78.4.980. Cited 2019 Aug 14.

59. Altman R, Rouvier J, Gurfinkel E, D'Ortencio O, Manzanel R, de La Fuente L, et al. Comparison of two levels of anticoagulant therapy in patients with substitute heart valves. J Thorac Cardiovasc Surg. 1991;101 (3):427-31 Available from: http://www.ncbi.nlm.nih.gov/pubmed/1999935. Cited 2019 Aug 14.

60. Nobuyoshi M, Hamasaki N, Kimura T, Nosaka H, Yokoi H, Yasumoto H, et al. Indications, complications, and short-term clinical outcome of percutaneous transvenous mitral commissurotomy. Circulation. 1989; 80(4):782-92 Available from: http://www.ncbi.nlm.nih.gov/pubmed/2 791243. Cited 2019 Aug 14

61. Schofer J, Siminiak T, Haude M, Herrman JP, Vainer J, Wu JC, et al. Percutaneous mitral annuloplasty for functional mitral regurgitation: results of the Carillon Mitral Annuloplasty Device European Union Study. Circulation. 2009;120(4):326-33 Available from: https://www.ahajournals.org/ doi/10.1161/CIRCULATIONAHA.109.849885. Cited 2019 Aug 14.

62. Calafiore AM, Gallina S, Di Mauro M, Gaeta F, lacò AL, D'Alessandro S, et al. Mitral valve procedure in dilated cardiomyopathy: repair or replacement? Ann Thorac Surg. 2001;71(4):1146-52 discussion 1152-3. Available from: http://www.ncbi.nlm.nih.gov/pubmed/11308151. Cited 2019 Aug 14.

63. Amoury RA, Bowman FO, Malm JR. Endocarditis associated with intracardiac prostheses. Diagnosis, management, and prophylaxis. J Thorac Cardiovasc Surg. 1966;51 (1):36-48 Available from: http://www.ncbinlm.nih.gov/ pubmed/5322465. Cited 2019 Aug 14.

64. David TE, Burns RJ, Bacchus CM, Druck MN. Mitral valve replacement for mitral regurgitation with and without preservation of chordae tendineae. $J$ Thorac Cardiovasc Surg. 1984;88(5 Pt 1):718-25 Available from: http://www. ncbi.nlm.nih.gov/pubmed/6492840. Cited 2019 Aug 14.

65. Crawford MH, Souchek J, Oprian CA, Miller DC, Rahimtoola S, Giacomini JC, et al. Determinants of survival and left ventricular performance after mitral valve replacement. Department of Veterans Affairs Cooperative Study on Valvular Heart Disease. Circulation. 1990;81(4):1173-81 Available from: http:// www.ncbi.nlm.nih.gov/pubmed/2317900. Cited 2019 Aug 14.

66. Fucci C, Sandrelli L, Pardini A, Torracca L, Ferrari M, Alfieri O. Improved results with mitral valve repair using new surgical techniques. Eur J Cardiothorac Surg. 1995;9(11):621-6 discuss 626-7. Available from: http:// www.ncbi.nIm.nih.gov/pubmed/8751250. Cited 2019 Aug 14.

67. Gammie JS, Zhao Y, Peterson ED, O'Brien SM, Rankin JS, Griffith BP. Lessinvasive mitral valve operations: trends and outcomes from the society of thoracic surgeons adult cardiac surgery database. Ann Thorac Surg. 2010; 90(5):1401-1410.e1 Available from: https://linkinghub.elsevier.com/retrieve/ pii/S000349751001218X. Cited 2019 Aug 14.

68. Wendel H. Coating-techniques to improve the hemocompatibility of artificial devices used for extracorporeal circulation. Eur J Cardio-Thoracic Surg. 1999;16(3):342-50 Available from: https://academic.oup.com/ejcts/ article-lookup/doi/10.1016/S1010-7940(99)00210-9. Cited 2019 Aug 14.

69. Flameng W, Herijgers P, Bogaerts K. Recurrence of mitral valve regurgitation after mitral valve repair in degenerative valve disease. Circulation. 2003; 107(12):1609-13 Available from: http://www.ncbi.nlm.nih.gov/pubmed/1266 8494. Cited 2019 Aug 14

70. Rozich JD, Carabello BA, Usher BW, Kratz JM, Bell AE, Zile MR. Mitral valve replacement with and without chordal preservation in patients with chronic mitral regurgitation. Mechanisms for differences in postoperative ejection performance. Circulation. 1992;86(6):1718-26 Available from: http://www. ncbi.nlm.nih.gov/pubmed/1451243. Cited 2019 Aug 29.
71. Jamieson WR, Edwards FH, Schwartz M, Bero JW, Clark RE, Grover FL. Risk stratification for cardiac valve replacement. National Cardiac Surgery Database. Database Committee of The Society of Thoracic Surgeons. Ann Thorac Surg. 1999;67(4):943-51 Available from: http://www.ncbi.nlm.nih.gov/ pubmed/10320233. Cited 2019 Aug 14.

72. Webb JG, Harnek J, Munt BI, Kimblad PO, Chandavimol M, Thompson CR, et al. Percutaneous transvenous mitral annuloplasty. Circulation. 2006;113(6): 851-5 Available from: http://www.ncbi.nlm.nih.gov/pubmed/16461812. Cited 2019 Aug 14.

73. Ling LH, Enriquez-Sarano M, Seward JB, Orszulak TA, Schaff HV, Bailey KR, et al. Early surgery in patients with mitral regurgitation due to flail leaflets: a long-term outcome study. Circulation. 1997;96(6):1819-25 Available from: http://www.ncbi.nlm.nih.gov/pubmed/9323067. Cited 2019 Aug 14.

74. Vyavahare N, Hirsch D, Lerner E, Baskin JZ, Schoen FJ, Bianco R, et al. Prevention of bioprosthetic heart valve calcification by ethanol preincubation. Efficacy and mechanisms. Circulation. 1997;95(2):479-88 Available from: http://www.ncbi.nlm.nih.gov/pubmed/9008467. Cited 2019 Aug 14.

75. Perier P, Deloche A, Chauvaud S, Fabiani JN, Rossant P, Bessou JP, et al. Comparative evaluation of mitral valve repair and replacement with Starr, Björk, and porcine valve prostheses. Circulation. 1984;70(3 Pt 2):1187-92 Available from: http://www.ncbi.nlm.nih.gov/pubmed/6744563. Cited 2019 Aug 14.

76. Ambler G, Omar RZ, Royston P, Kinsman R, Keogh BE, Taylor KM. Generic, simple risk stratification model for heart valve surgery. Circulation. 2005; 112(2):224-31 Available from: https://www.ahajournals.org/doi/10.1161/ CIRCULATIONAHA.104.515049. Cited 2019 Aug 14.

77. Chua YL, Schaff HV, Orszulak TA, Morris JJ. Outcome of mitral valve repair in patients with preoperative atrial fibrillation. Should the maze procedure be combined with mitral valvuloplasty? J Thorac Cardiovasc Surg. 1994;107(2): 408-15 Available from: http://www.ncbi.nlm.nih.gov/pubmed/8302059. Cited 2019 Aug 14.

78. Bolling SF, Li S, O'Brien SM, Brennan JM, Prager RL, Gammie JS. Predictors of mitral valve repair: clinical and surgeon factors. Ann Thorac Surg. 2010;90(6): 1904-12 Available from: http://www.ncbi.nlm.nih.gov/pubmed/21095334. Cited 2019 Aug 14.

79. Masur H, Johnson WD. Prosthetic valve endocarditis. J Thorac Cardiovasc Surg. 1980;80(1):31-7 Available from: http://www.ncbi.nlm.nih.gov/ pubmed/6991824. Cited 2019 Aug 14.

80. Braun J, van de Veire NR, Klautz RJM, Versteegh MIM, Holman ER, Westenberg JJM, et al. Restrictive mitral annuloplasty cures ischemic mitral regurgitation and heart failure. Ann Thorac Surg. 2008;85(2):430-6 discussion 436-7. Available from: https://inkinghub.elsevier.com/retrieve/pii/ S0003497507018036. Cited 2019 Aug 14.

81. John S, Bashi W, Jairaj PS, Muralidharan S, Ravikumar E, Rajarajeswari T, et al. Closed mitral valvotomy: early results and long-term follow-up of 3724 consecutive patients. Circulation. 1983;68(5):891-6 Available from: https:// www.ahajournals.org/doi/10.1161/01.CIR.68.5.891. Cited 2019 Aug 14.

82. Gammie JS, O'Brien SM, Griffith BP, Ferguson TB, Peterson ED. Influence of hospital procedural volume on care process and mortality for patients undergoing elective surgery for mitral regurgitation. Circulation. 2007;115(7): 881-7 Available from: http://www.ncbi.nlm.nih.gov/pubmed/17283266. Cited 2019 Aug 14.

83. Bodner J, Wykypiel H, Wetscher G, Schmid T. First experiences with the da Vinci operating robot in thoracic surgery. Eur J Cardiothorac Surg. 2004; 25(5):844-51 Available from: https://academic.oup.com/ejcts/article-lookup/ doi/10.1016/.jejcts.2004.02.001. Cited 2019 Aug 14.

84. David TE, Armstrong S, Sun Z, Daniel L. Late results of mitral valve repair for mitral regurgitation due to degenerative disease. Ann Thorac Surg. 1993; 56(1):7-12 discussion 13-4. Available from: http://www.ncbi.nlm.nih.gov/ pubmed/8328879. Cited 2019 Aug 14.

85. Cox UL. A perspective of postoperative atrial fibrillation in cardiac operations. Ann Thorac Surg. 1993;56(3):405-9 Available from: http://www.ncbi.nlm.nih. gov/pubmed/8379709. Cited 2019 Aug 14.

86. Hickey MS, Smith LR, Muhlbaier LH, Harrell FE, Reves JG, Hinohara T, et al. Current prognosis of ischemic mitral regurgitation. Implications for future management. Circulation. 1988;78(3 Pt 2):151-9 Available from: http://www. ncbi.nlm.nih.gov/pubmed/2970346. Cited 2019 Aug 14.

87. Kang D-H, Kim JH, Rim JH, Kim M-J, Yun S-C, Song J-M, et al. Comparison of early surgery versus conventional treatment in asymptomatic severe mitral regurgitation. Circulation. 2009;119(6):797804 Available from: https://www.ahajournals.org/doi/10.1161/ CIRCULATIONAHA.108.802314. Cited 2019 Aug 14. 
88. Acar J, lung B, Boissel JP, Samama MM, Michel PL, Teppe JP, et al. AREVA: multicenter randomized comparison of low-dose versus standard-dose anticoagulation in patients with mechanical prosthetic heart valves. Circulation. 1996;94():2107-2112. Available from: https://www.ahajournals. org/doi/10.1161/01.CIR.94.9.2107. Cited 2019 Aug 14.

89. Fattouch K, Guccione F, Sampognaro R, Panzarella G, Corrado E, Navarra E, et al. POINT: efficacy of adding mitral valve restrictive annuloplasty to coronary artery bypass grafting in patients with moderate ischemic mitral valve regurgitation: a randomized trial. J Thorac Cardiovasc Surg. 2009; 138(2):278-85 Available from: https://linkinghub.elsevier.com/retrieve/pii/ S0022522308019326. Cited 2019 Aug 14.

90. King RM, Schaff HV, Danielson GK, Gersh BJ, Orszulak TA, Piehler JM, et al. Surgery for tricuspid regurgitation late after mitral valve replacement. Circulation. 1984;70(3 Pt 2):1193-7 Available from: http://www.ncbi.nlm.nih. gov/pubmed/6744564. Cited 2019 Aug 14

91. Abascal VM, Wilkins GT, O'Shea JP, Choong CY, Palacios IF, Thomas JD, et al. Prediction of successful outcome in 130 patients undergoing percutaneous balloon mitral valvotomy. Circulation. 1990;82(2):448-56 Available from: https://www.ahajournals.org/doi/10.1161/01.CIR.82.2.448. Cited 2019 Aug 29.

92. Magne J, Pibarot P, Dagenais F, Hachicha Z, Dumesnil JG, Sénéchal M. Preoperative posterior leaflet angle accurately predicts outcome after restrictive mitral valve annuloplasty for ischemic mitral regurgitation. Circulation. 2007;115(6):782-91 Available from: https://www.ahajournals.org/ doi/10.1161/CIRCULATIONAHA.106.649236. Cited 2019 Aug 14.

93. Rossiter SJ, Stinson EB, Oyer PE, Miller DC, Schapira JN, Martin RP, et al. Prosthetic valve endocarditis. Comparison of heterograft tissue valves and mechanical valves. J Thorac Cardiovasc Surg. 1978;76(6):795-803 Available from: http://www.ncbi.n/m.nih.gov/pubmed/713586. Cited 2019 Aug 14

94. Jamieson WR, Rosado LJ, Munro Al, Gerein AN, Burr LH, Miyagishima RT, et al. Carpentier-Edwards standard porcine bioprosthesis: primary tissue failure (structural valve deterioration) by age groups. Ann Thorac Surg. 1988; 46(2):155-62 Available from: http://www.ncbi.nlm.nih.gov/pubmed/3401075. Cited 2019 Aug 14

95. Kosakai Y, Kawaguchi AT, Isobe F, Sasako Y, Nakano K, Eishi K, et al. Cox maze procedure for chronic atrial fibrillation associated with mitral valve disease. J Thorac Cardiovasc Surg. 1994;108(6):1049-54 discussion 1054-5. Available from: http://www.ncbi.nlm.nih.gov/pubmed/7983874 Cited 2019 Aug 14.

96. Borger MA, Alam A, Murphy PM, Doenst T, David TE. Chronic ischemic mitral regurgitation: repair, replace or rethink? Ann Thorac Surg. 2006;81(3): 1153-61 Available from: http://www.ncbi.nlm.nih.gov/pubmed/16488757. Cited 2019 Aug 14.

97. Mohty D, Orszulak TA, Schaff HV, Avierinos J-F, Tajik JA, Enriquez-Sarano M. Very long-term survival and durability of mitral valve repair for mitral valve prolapse. Circulation. 2001;104(suppl 1):1-1-7 Available from: http://www. ncbi.nlm.nih.gov/pubmed/11568020. Cited 2019 Aug 14.

98. David TE, Omran A, Armstrong S, Sun Z, Ivanov J. Long-term results of mitral valve repair for myxomatous disease with and without chordal replacement with expanded polytetrafluoroethylene sutures. J Thorac Cardiovasc Surg. 1998;115(6):1279-85 discussion 1285-6. Available from: https://linkinghub. elsevier.com/retrieve/pii/S0022522398702107. Cited 2019 Aug 14.

99. Aranki SF, Shaw DP, Adams DH, Rizzo RJ, Couper GS, VanderVliet M, et al. Predictors of atrial fibrillation after coronary artery surgery. Circulation. 1996; 94(3):390-7 Available from: https://www.ahajournals.org/doi/10.1161/01.CIR. 94.3.390. Cited 2019 Jul 3.

100. Cohn L, Rizzo R, Adams D, Couper G, Sullivan T, Collins JJ, et al. The effect of pathophysiology on the surgical treatment of ischemic mitral regurgitation: operative and late risks of repair versus replacement. Eur J Cardio-Thoracic Surg. 1995;9(10):568-74 Available from: https://academic.oup.com/ejcts/ article-lookup/doi/10.1016/S1010-7940(05)80008-9. Cited 2019 Aug 14.

101. Dreyfus G, Serraf A, Jebara VA, Deloche A, Chauvaud S, Couetil JP, et al. Valve repair in acute endocarditis. Ann Thorac Surg. 1990;49(5):706-11 discussion 712-3. Available from: http://www.ncbi.nlm.nih.gov/pubmed/233 9926. Cited 2019 Aug 14

102. Braun J, Bax JJ, Versteegh MIM, Voigt PG, Holman ER, Klautz RJM, et al. Preoperative left ventricular dimensions predict reverse remodeling following restrictive mitral annuloplasty in ischemic mitral regurgitation. Eur J Cardiothorac Surg. 2005;27(5):847-53 Available from: https://academic.oup. com/ejcts/article-lookup/doi/10.1016/j.ejcts.2004.12.031. Cited 2019 Aug 14.

103. David TE, Bos J, Rakowski H. Mitral valve repair by replacement of chordae tendineae with polytetrafluoroethylene sutures. J Thorac Cardiovasc Surg.
1991;101(3):495-501 Available from: http://www.ncbi.nlm.nih.gov/pubmed/1 999944. Cited 2019 Aug 14.

104. Ben Farhat M, Ayari M, Maatouk F, Betbout F, Gamra H, Jarra M, et al. Percutaneous balloon versus surgical closed and open mitral commissurotomy: seven-year follow-up results of a randomized trial. Circulation. 1998;97(3):245-50 Available from: http://www.ncbi.nlm.nih.gov/ pubmed/9462525. Cited 2019 Aug 14.

105. Chauvaud S, Jebara V, Chachques JC, el Asmar B, Mihaileanu S, Perier P, et al. Valve extension with glutaraldehyde-preserved autologous pericardium. Results in mitral valve repair. J Thorac Cardiovasc Surg. 1991; 102(2):171-7 discussion 177-8. Available from: http://www.ncbi.nlm.nih.gov/ pubmed/1907700. Cited 2019 Aug 14

106. Seeburger J, Borger MA, Falk V, Kuntze T, Czesla M, Walther T, et al. Minimal invasive mitral valve repair for mitral regurgitation: results of 1339 consecutive patients. Eur J Cardiothorac Surg. 2008;34(4):760-5 Available from: https://academic.oup.com/ejcts/article-lookup/doi/10.1016/j.ejcts.2008. 05.015. Cited 2019 Aug 14.

107. Schubert SA, Mehaffey JH, Charles EJ, Kron IL. Mitral valve repair. Surg Clin North Am. 2017:97(4):867-88 Available from: http://www.ncbi.nlm.nih.gov/ pubmed/28728720. Cited 2019 Aug 5.

108. Diodato $M$, Chedrawy EG. Coronary artery bypass graft surgery: the past, present, and future of myocardial revascularisation. Surg Res Pract. 2014; 2014 Available from: https://www.hindawi.com/journals/srp/2014/726158/. Cited 2019 May 23.

109. Lillehei CW, Levy MJ, Bonnabkau RC. 81. Mitral valve replacement with preservation of papillary muscles and chordae tendineae. Am J Cardiol. 1964;13(1):117-8 Available from: https://linkinghub.elsevier.com/retrieve/pii/ 000291496490311 X. Cited 2019 Aug 6.

110. Greelish JP, Cohn LH, Leacche M, Mitchell M, Karavas A, Fox J, et al. Minimally invasive mitral valve repair suggests earlier operations for mitral valve disease. J Thorac Cardiovasc Surg. 2003;126(2):365-71 discussion 3713. Available from: http://www.ncbi.nlm.nih.gov/pubmed/12928632. Cited 2019 Aug 6.

111. Nifong LW, Chitwood WR, Pappas PS, Smith CR, Argenziano M, Starnes VA, et al. Robotic mitral valve surgery: a United States multicenter trial. J Thorac Cardiovasc Surg. 2005;129(6):1395-404 Available from: http://www.ncbi.nlm. nih.gov/pubmed/15942584. Cited 2019 Aug 6.

112. MCGOON, DC. Repair of mitral insufficiency due to ruptured chordae tendineae. J Thorac Cardiovasc Surg. 1960;39:357-62 Available from: https:// ci.nii.ac.jp/naid/10016180959/. Cited 2019 Aug 6.

113. Cohn LH, Couper GS, Aranki SF, Rizzo RJ, Kinchla NM, Collins JJ. Longterm results of mitral valve reconstruction for regurgitation of the myxomatous mitral valve. J Thorac Cardiovasc Surg. 1994;107(1):143-50 discussion 150-1. Available from: http://www.ncbi.nlm.nih.gov/pubmed/ 8283877. Cited 2019 Aug 6

114. Mohr FW, Falk V, Diegeler A, Walther T, Gummert JF, Bucerius J, et al. Computer-enhanced "robotic" cardiac surgery: experience in 148 patients. J Thorac Cardiovasc Surg. 2001:121(5):842-53 Available from: https:// linkinghub.elsevier.com/retrieve/pii/S0022522301347220. Cited 2019 Aug 14.

\section{Publisher's Note}

Springer Nature remains neutral with regard to jurisdictional claims in published maps and institutional affiliations.

Ready to submit your research? Choose BMC and benefit from

- fast, convenient online submission

- thorough peer review by experienced researchers in your field

- rapid publication on acceptance

- support for research data, including large and complex data types

- gold Open Access which fosters wider collaboration and increased citations

- maximum visibility for your research: over $100 \mathrm{M}$ website views per year

At BMC, research is always in progress.

Learn more biomedcentral.com/submissions 